\author{
Asian Journal of \\ Medical and Biological Research \\ ISSN 2411-4472 (Print) 2412-5571 (Online) \\ www.ebupress.com/journal/ajmbr
}

\title{
Article \\ Study of traditional fish drying activities at Atrai upazilla of Naogaon district in Bangladesh
}

\author{
Shishir Kumar dey ${ }^{1}$, Md. Rayhan Hossain ${ }^{1 *}$, Fawzia Adib Flowra ${ }^{3}$, Sayeeda Sultana ${ }^{2}$ and Rubia Akter ${ }^{2}$ \\ ${ }^{1}$ Bangladesh Fisheries Research Institute, Freshwater Station, Mymensingh -2201, Bangladesh ${ }^{2}$ Bangladesh \\ Fisheries Research Institute, Head Quarter, Mymensingh -2201, Bangladesh \\ ${ }^{3}$ University of Rajshahi, Department of Fisheries, Rajshahi -6205, Bangladesh \\ *Corresponding author: Md. Rayhan Hoissain, Scientific Officer, Freshwater Station, Mymensingh-2201, \\ Bangladesh. Phone: +8801735851266; E-mail: rfaa_hossain@yahoo.com
}

Received: 15 November 2016/Accepted: 13 December 2016/ Published: 29 December 2016

\begin{abstract}
The investigation was conducted on traditional fish drying activities of the Atrai upazila under Naogaon district from July 2011 to December 2011. There was only one fish drying point was found in study area. The observed fish drying points are seasonal (from July to December). There are sixteen fish species were identified for drying among study area. Most of the raw fish collect from local market or Atria River. Transportation of raw fish was done by non-mechanized van or by head load of the labour. Price of the raw fish varied according to the species, size and availability. It is observed that September-October peak period for drying. The rate of mixing salt in the study area was found as $1 \mathrm{~kg}$ salt for $12 \mathrm{~kg}$ of raw fish. At normal weather condition drying duration recorded to be varied from 2-5 days depend on the size of the raw fish. Plastic, jute sack and sometimes bamboo baskets were used for packaging purpose. The marketing channel is too small here. It was found that all the dried fish product in study areas, carried to the Sayadpur dry fish wholesale market in Nilphamary district directly by producers. The annual production of dried fish range $6000-8000 \mathrm{Kg}$. The highest price per kg dried fish was found as 400-550 Tk (Baim) and the lowest was found as 90-120 Tk (Punti, Darkina, Colisa). The cost benefit ratio for fish drying activities of study area was 1:0.671. The dry fish trader faced some problem such as insufficient credit, lack of raw fish insect infestation, storage and marketing facilities. From the present study some recommendations were also formulated to minimize the problem.
\end{abstract}

Keywords: raw fish; dry fish; washing; salting; wholesale market

\section{Introduction}

Bangladesh has a vast inland open water bodies in the form of river, estuary, beel, flood plain etc. It possess about 4652665 ha of Inland waters and 67,51,000 ha of marine waters in Bangladesh. In Inland water 40,24,934 ha. are open waters, River and estuary 10,31,563 ha. Beel 1,14,161 ha. kaptai lake 68800 ha. and flood plain 28,10,410 ha. (DoF, 2011). There are 260 fish species are available (Rahman, 1989) in freshwater body. Fisheries resources plays an important role in national economy of Bangladesh. Fishery is very promising and important for creating employment, earning foreign exchange alleviating poverty and improving nutritional status of the people. In the national export income (2009-2010) the contribution of the fisheries sector is second. On the export income $2.70 \%$ comes from the fisheries sector. During the year 2009-2010, Bangladesh earned 3408.51 crore taka by exporting of 77584.12 metric ton fish and fishery products to foreign country (DoF, 2011).

Drying fish is an important source of protein in Bangladesh and it is also the cheapest and easiest method. Fish is very perishable commodity because of its low acid which supports the growth of pathogens (micro organisms causing disease) careful handling and rapid processing are essential. The fish is usually neither chilled nor 
adequately protected from the sun both on board fishing vessels and at the landing site. Basic principles of hygiene may have been unknown or seldom applied so that by the time processors buy the fish, it may already have reached various stages of spoilage. Bacterial and enzymatic spoilage is the most important of this stage. Bacteria present on the surface and in the guts of the dead fish multiply rapidly, invading the flesh. By the time there is evidence of slime on the skin and unpleasant smell, it is too late to take any preventing action. At ambient tropical temperature fresh whole fish in rendered inedible within twelve hours (FAO, 1981) removing the guts and disposing of them properly will help inhibit flesh deterioration.

Sun drying is the most widely used method of fish preservation. This method is also considered as the least expensive method of preservation. Drying involves removal of water content from the fish body. In Sun drying this process is carried out by exposing target fish directly under the sun. This is usually done in the open air using solar energy to evaporate the water content in the fish. Natural air carried away the evaporated water from fish body. For export quite a good amount of catch are preserved specially in freeze and sun dried conditions. Among the export quantity of fish a good amount is occupied by the dried fish which are sold in a number of countries of the world. In 2010-2011 Bangladesh export 622 metric tons dry fish value of Tk. 25.06 Core Tk. (DoF, 2011). Details data of exported of dry fish from Bangladesh (2003-2004 to 2010-2011) are presented in Table 1.1. If necessary steps could be taken to set up modern fish drying factories, the products can be made and keep in hygienic ways then demand of this commodity will rise up and Bangladesh will earn more foreign currency.

Traditionally drying in often rudimentary and good hygiene is nearly practiced. During the rainy season, when humidity levels are high, sufficient drying cannot be achieved using traditional methods in such conditions, stored dried fish will also reabsorbs moisture and become susceptible to bacterial, fungal or insect attack. It is relished by many people of coastal, central and North-eastern districts. However, the physical and organoleptic qualities of many traditional sun-dried products are un-satisfactory for human consumption (Nowsad, 2005).

Traditional sun-drying is carried out in the open air, using the energy of the sun to evaporate the water and air currents to carry away to vapour. Low humidity facilitates evaporation. However, during initial stage of drying, evaporated vapour makes the surrounding environment humid. Therefore, strong air flow is needed to carry away the vapour rapidly. Theoretically, moisture content of the final product should be reduced to less than 15$16 \%$ where most of the microbiological and enzymatic activities are showed down or stopped. In commercial processing water content is often higher when storage times are short, where salt is used in the processing and consumers prefer an intermediate moisture product. Local consumers generally prefer unsalted products.

\section{Materials and Methods}

\subsection{Location of the study area}

Atrai upazila is situated under Naogaon district it is bounded in the south side by Natore district, in the north side Raninagar and in the west side Baghmara, In the east Singra district. Atrai is located at $24^{\circ} 36^{\prime} 45^{\prime \prime} \mathrm{N}$ $88^{\circ} 58^{\prime} 15^{\prime \prime} \mathrm{E} 24.6125^{\circ} \mathrm{N} 88.9708^{\circ} \mathrm{E}$. It has 30570 units of house hold and total area $284.41 \mathrm{~km}^{2}$. ("Population Census Wing, BBS.")

\subsection{Period of the data collection}

This study was conducted for a period of 6 months (July 2011 to December 2011) at Atrai Upazilla under Naogaon district. Frequent field visits and interviews of the dry fish farmers were made to collect necessary data on fish drying.

\subsection{Data collection method}

Rapid Rural Appraisal (RRA) tools were applied with different degree of effectiveness was done on certain tools whenever required. The different RRA tools applied.

\subsection{Survey and interview method}

A survey method was done over the study area of exact information to fulfillment the research work. A survey was conducted on the source of raw materials, transportation and processing of dried fish using questionnaires interviews among the cross section of people including fish drying professionals.

\subsection{Data analysis technique}

The information thus collected, were analyzed of bring it to bear on the hypothesis, simple tabulation and statistical calculation like proportions, average etc. The results have been shown in descriptive tabular and graphical presentation. 


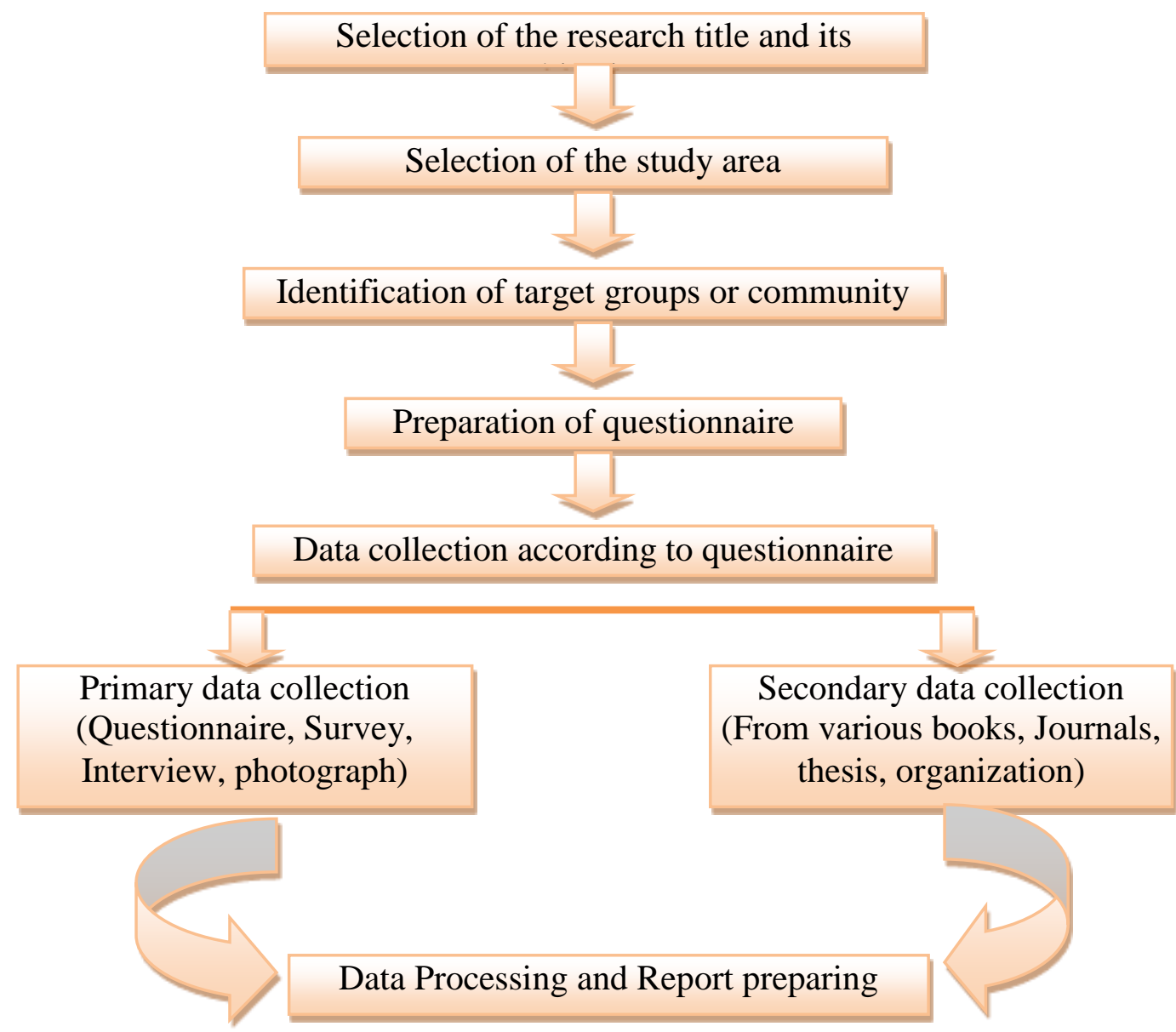

Figure 1. Design of the research methodology.

\section{Results}

\subsection{Fish drying yard}

Traditionally sun-drying is carries out in the open air, using the energy of the sun to evaporate the water and air current to carry away the vapour. For this reason in the study area, it was observed that fishes were mainly dried on the bank of Atrai river and both side of the Rail line of Ahsangonj Station. In this open place sufficient sunlight and wind are available which was suitable for drying activitics. There is only one fish drying points (Vor tatulia) observed in the study area. Ahsangonj bazer is a largest fish landing center in the study area. For this reason raw fish are available here.The main source of the raw fish is comes from Atrai river and nearest beels of Ahsangonj. Most of the fish drying yard build on the basis of raw material availability, communication facilities and market demand.

\subsection{Description of fish drying yard}

In this study area, it was observed that most of the fish drying yard has a well marked territory. The bamboo marked territory is called Khola. Sun drying for business purpose is generally carried out on rack made of bamboo splits and poles, sometimes fishing net directly on earth used for sun drying. Household consumption is performed in small scale by using bamboo baskets.

\subsection{Utensils used for fish drying}

For dressing purposes some sharp knives, hacksaws and such utensils were used. Plastic and Bamboo buckets were also used for washing. The finished products were kept either in bamboo-made containers, jute made bags (Figure 2). 

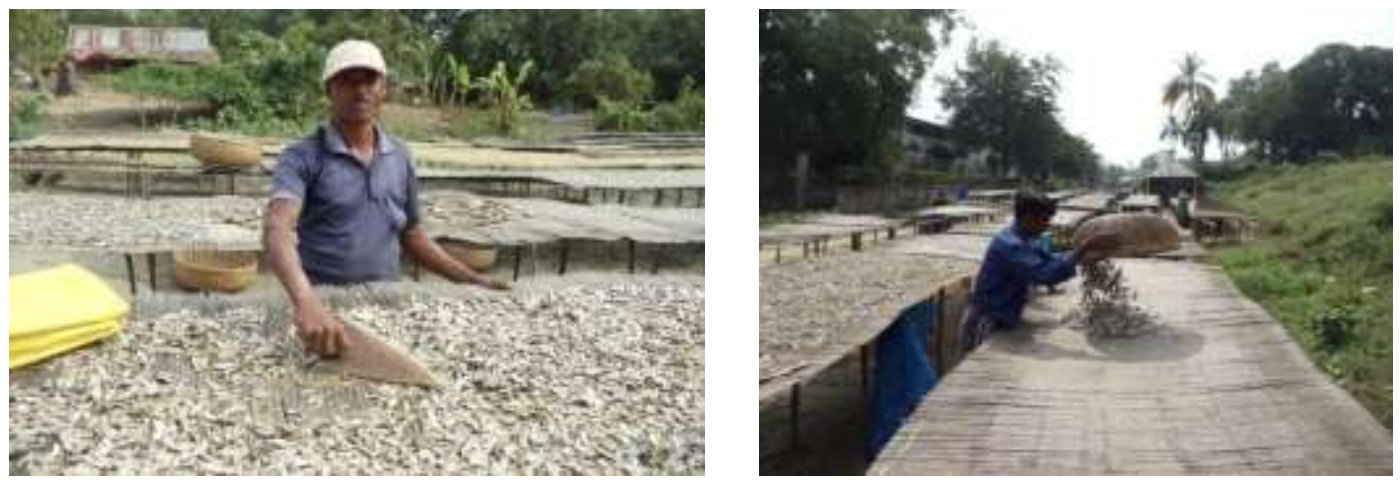

Figure 2. Utensils used for fish drying.

\subsection{People involved}

To operation the fish drying activities two categories of manpower are needed. The first categories consists of experienced person who can operate total activities, invest money, collect raw materials and lastly cell the product. Second categories consist of the labour of both sex. Usually five to seven labours needed to conduct drying operation. But in the peak period of drying it was found that 15-20 labours were engaged. The labour charge was daily paid or Monthly. People involve of different fish drying yard shown Table 1.

Table 1. Number of fish drying rack in Vor-tatulia fish drying Point.

\begin{tabular}{l|l|l}
\hline Sl. No. & Name of the fish drying Point & Number of the fish drying rack \\
\hline 1 & Vor- tetulia & 60 \\
\hline
\end{tabular}

\subsection{Species used in sun drying}

Variety of fishes is being used in sun drying in the study areas. For commercial sun drying species selection depends on both availability and market demand. A total sixteen types of fish species were identified used for drying among study area. Fish species that are used in sun drying can be divided into two main categories (i) more demandful fish species (95\% of total dried fish) and (ii) less demandful fish species (5\% of total dried fish). More demandful include those fish, which are targeted by the dry fish trader to be dried. Less demandful fish include punti, chanda, chingri etc. These species include different fish species that remain mixed with major fish species in small quantity, more demandful fish include colisa, mola, bele, guchi, tara baim, boal, tengra etc.A list of fish used for traditional sun drying in different fish drying yard at Atrai are shown in Table 2.

Table 2. Species used for sun drying in Vor-tatulia in Atrai upazila.

\begin{tabular}{lll}
\hline Sl. No. & Fish Name (Local) & Scientific Name \\
\hline 01 & Punti & Puntius sp. \\
02 & Chanda & Chanda sp. \\
03 & Colisa & Colisa sp. \\
04 & Moa, Mola & Amblypharyngodon mola \\
05 & Guchi & Mastacembelus pancalus \\
06 & Darkina & Esomus danricus \\
07 & Chapila, Khoira & Gudusia chapra \\
08 & Taki, Saitan & Channa punctata \\
09 & Kakila & Xenentodon cancila \\
10 & Tengra & Mystus vittatus \\
11 & Tara baim & Macrognathus aculeatus \\
12 & Bele, Baila & Glossogobius giuris \\
13 & Boal & Wallago attu \\
14 & Batashi & Pseudeutropius antherinoides \\
15 & Icha, Chingri & Macrobrachium sp. \\
16 & Silver carp & Hypophthalmicthys molitrix \\
\hline
\end{tabular}




\subsection{Fish drying season}

In the study area fish drying generally starts in July and end in January. Peak drying is observed SeptemberOctober because of season sufficient sunlight was available throughout the day. Fish drying activities mainly depends on the raw materials availability, weather condition and market demand.

\subsection{Method of traditional sun drying}

The traditional fish drying process completed in some steps. The following steps normally followed in commercial fish drying.

\subsubsection{Collection of raw fish}

Most of the dry fish farmer collect raw fishes from local fish market and directly form Atrai rivers and other sources of that area. Collection of raw fish by fishing mostly observed. Most of the fish for drying purposes were collected from the local fish bazar. It is observed that collection of raw fish from landing centers/markets 90\% and own Dry 10\%. In most cases, it was observed that low quality damaged fishes were brought from the local fish markets and landing centers for drying. The amount of collection raw fish depends on price and availability of raw fish (Figure 3).
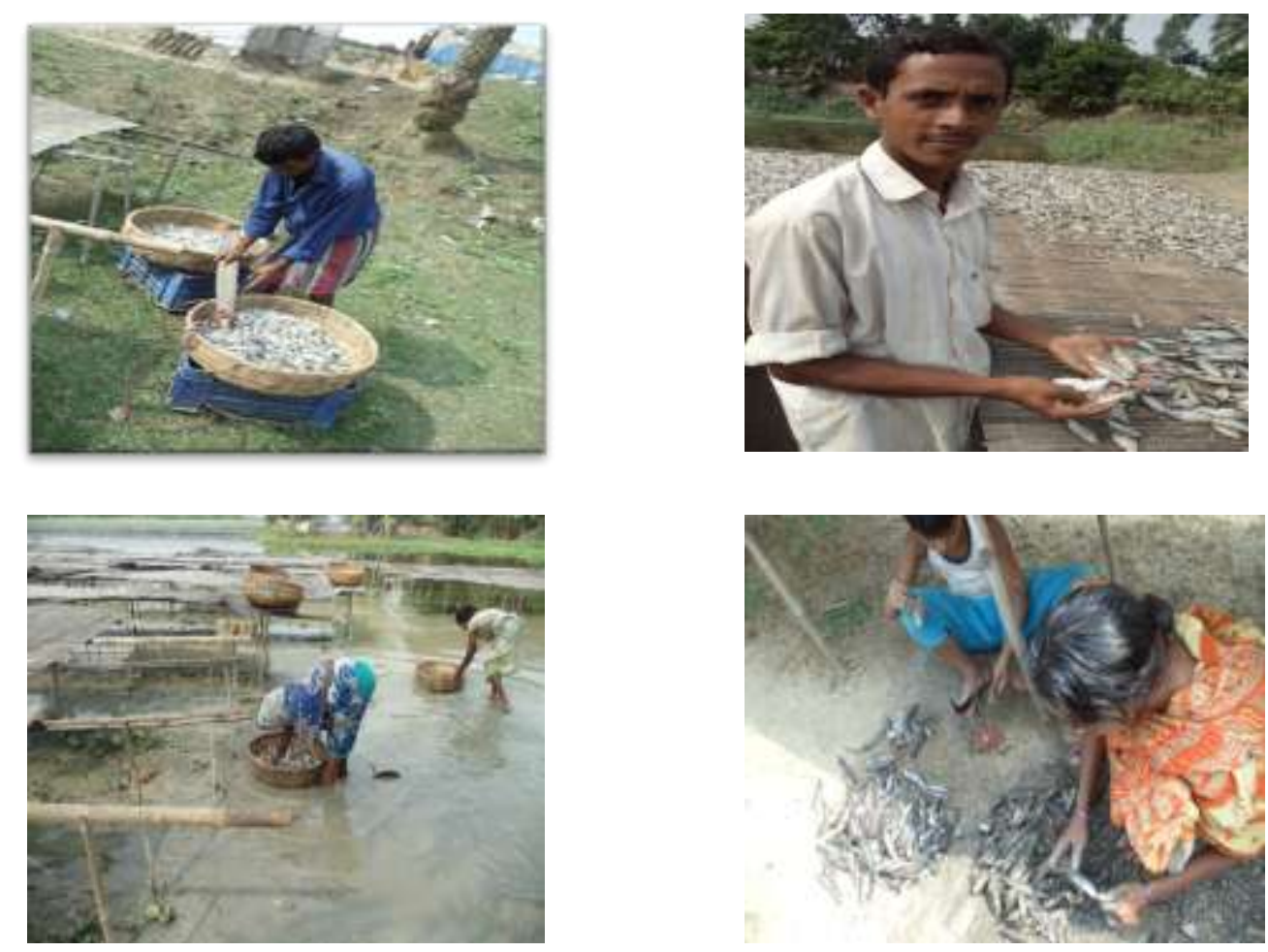

Figure 3. Method of traditional fish drying.

\subsubsection{Transportation}

Transportation of raw fish from fish landing centers to fish drying point was mainly done by non-mechanized van, richshaw, bicycle or by head load or shoulder load of the labors. Dry fish transportation from drying point to whole sale market done by Train.

\subsubsection{Sorting}

Sorting is necessary step before drying. Sorting is done on the drying yard. Both male and female workers engaged for sorting of fish. The purpose of sorting depending on the sorting of small and large fish, sorting out weeds, other particles, shorting fresh and rotten fish species. Sorting also practice after fish driying to separated fish according to the quality and size of the dried fish.

\subsubsection{Washing}

A primary washing is done after sorting. In most cases, dry fish farmers washed their raw fish with river water as there was no good water supply sources in drying areas and few dry fish farmers used pond water for this 
purpose. It was also found that, many dry fish farmers did not wash their raw fish. Final washing is done after scaling and degutting.

\subsubsection{Salting}

Use of salt important for proper fish drying. Salt protect the dry fish from spoilage and ensure long time preservation. It was found that dry fish farmers in the studied areas used salt with raw fishes before drying. The rate of mixing salt in the study area was found as $1 \mathrm{Kg}$ salt for $12 \mathrm{Kg}$ of fishes. All the dry fish farmers used non-brand commercial salt for this purpose.

\subsubsection{Drying under the sun}

All the fishes are dried under sun. The process of drying varies according to the fish size and also some extent, choice of the consumers. For comparatively large scale fish drying, bamboo made rack of 1.05-1.2 meter high from earth is used in most cases. A bamboo splits made mat is used on the rack over which raw fishes were spread for drying. In some places fishes were spread on fishing seine nets directly on earth without using any bamboo.

\subsubsection{Drying duration}

Drying duration extremely varied with weather conditions like available sunlight, temperature, relative humidity, wind flow, raining status etc. In the surveyed areas, at normal weather condition (enough sunlight, temperature, humidity, and no rain) drying duration recorded to be varied from 2-6 days depending on the size of the raw fishes. Duration of fish drying on different fish species in study area is given Table 3.

Table 3. Duration of different fish drying at suitable condition.

\begin{tabular}{|c|c|c|c|c|}
\hline Sl. No. & Fish Name & Scientific Name & Drying duration (day) & $\begin{array}{l}\text { Turning over a day } \\
\text { based on species }\end{array}$ \\
\hline 01 & Punti & Puntius sp. & $2-3$ & \multirow{16}{*}{ 7-8 Times } \\
\hline 02 & Chanda & Chanda sp. & 2 & \\
\hline 03 & Colisa & Colisa $\mathrm{sp}$ & $2-3$ & \\
\hline 04 & Silver carp & Hypophthalmichthys molitrix & 6 & \\
\hline 05 & Moa, Mola & Amblypharyngodon mola & 2 & \\
\hline 06 & Darkina & Esomus danricus & 3 & \\
\hline 07 & Chapila, Khoira & Gudusia chapra & $2-3$ & \\
\hline 08 & Taki, Saitan & Channa punctata & $2-3$ & \\
\hline 09 & Kakila & Xenentodon cancila & $2-3$ & \\
\hline 10 & Tengra & Mystus vittatus & $3-4$ & \\
\hline 11 & Guchi & Mastacembelus pancalus & $5-6$ & \\
\hline 12 & Tara baim & Macrognathus aculeatus & $5-6$ & \\
\hline 13 & Bele, Baila & Glossogobius giuris & 4 & \\
\hline 14 & Boal & Wallago attu & $5-6$ & \\
\hline 15 & Batashi & Pseudeutropius antherinoides & 3 & \\
\hline 16 & Icha, Chingri & Macrobrachium sp. & $1-2$ & \\
\hline
\end{tabular}

\subsubsection{Packaging}

After sorting, the dried fishes were bagged into a plastic and jute bag for easy handling. Sometimes bamboo baskets were also used for this purpose. The size varied with the quantity of the product to be stored. When the dried fish marketing use jute sacks and scaled. When packed the fish drying farmers use vacuum pack.

\subsubsection{Storage of dried fish}

A well storage system gives the product safe and quality. Storage of dried fish are found to be performed in a tent made of thin plastic sheet and bamboo splits. This tent is usually made in the place of fish drying. Bagged dried fishes were kept into these tents for temporary storage until marketing or selling to the local vendors (Plate 4.9). If any infestation was found during storage the stored product was again sun dried for 1-2 days and restored. 
3.7.10. Women Participation in fish drying activities

Now a day's women participation is an important and hopeful in fish drying activities. In my research area the women participation is also a good one. Many women are running their business successfully through fish drying activities. They invest small amount of money and produce salted dry fish and non-salted dry fish in different fish species near their house and yard. In this way they can self dependent in the society. In Daspara village 300 Hindu families lived. They were running their business through fish drying activities professionally. For fish drying activities they took money from Money lenders on high interest. But PROSHIKA starts giving loan to women on fish drying activities from 1997 in a project. To produce safe and hygienic fish product they gave loan to 292 women that's amount was 56.70 lakh taka. By this time "PROSHIKA" gave training to 356 women for raising awareness and make safe fish dry products. Now the women are self dependent and earn 2500-3000 tk. On each month and develop their socio-economic status. (DOF-2009).

\subsubsection{Price of dry fish (final product)}

Price is the amount of money charged for a product. Pricing usually depends on the product average costs. Price of the dried fish varied on the size and quality of the product. The highest price per $\mathrm{Kg}$ of dried fish was found as 400-550 Tk (Baim), 400-500 Tk (Boal) and the lowest was found as 90-120 Tk (Punti, Darkina, Colisa) the price of dried fish are shown in the Table 4.

Table 4. Total benefit and investment (Tk.) of Vor-tatulia fish drying point.

\begin{tabular}{ll}
\hline Items & Total Taka \\
\hline Fish drying yard building cost & $6,00,000.00$ \\
Cost of raw fishes (Tk.) & $5,00,000.00$ \\
Marketing & $2,000.00$ \\
Labour cost & $50,000.00$ \\
Chemicals & 000.00 \\
Salt & $18,000.00$ \\
Packaging & $12,000.00$ \\
Miscellaneous & $15,000.00$ \\
Total cost & $11,97,000.00$ \\
Yearly production (Kg) & $8,000.00$ \\
Price of product sold (Tk.) & $2,00,0000.00$ \\
Net benefit & $8,03,000.00$ \\
Cost-benefit ratio & $\mathbf{1 : 0 . 6 7 1}$ \\
\hline
\end{tabular}

\subsubsection{Marketing of dried fish}

Marketing of any product is very important for a successful business. In the studied areas, dried fishes were marketed by the dry fish farmers at every 7-15 days interval. There is little information about the quality aspects of fresh fish and the dried products in different stages of marketing chains since no detailed survey was conducted in Bangladesh (Nurullah et al., 2005). It was found that almost all the dried fish product, dried in study areas, carried to the Sayadpur dry fish wholesale market in Nilphamary district. Very small amount of dried products were consumed locally. Marketing channel of dried fish in the study areas consisted of only dry fish farmers (producer).The marketing channel is so short here. In my study area the fish dry farmers are directly sold their product to wholesale market in Nilphamary district by train and there is no existence of fish drying Market and middlemen (Faria, Bapari etc.)

\section{Discussion}

Present investigation in the study area, it was observed that fishes were mainly dried on the bank of Atrai river and both side of the Ahsangong Station, Naogaon District. In this open place sufficient sunlight and wind are available which is suitable for drying activities. The bamboo marked territory is called khola.

Fish drying generally starts in July and end in January. Peak fish drying is observed September-October. Pervin (2004) reported that the traditional drying of fish depends on solar energy the dry fish producing period extends only from October to march. Collect raw fishes from local fish market and transportation by non-mechanized van, bicyele or by head load or shoulder load to the labours. Azam (2002) reported this types transportation of raw fish for drying. Fish drying is completed in few steps such as washing, sorting, dressing, washing, salting, drying on sun etc. This type traditional sun drying of fish was reported by Nowsad (2007). 
Use of salt is important step for proper fish drying. Some dry fish farmer use additional salt to increase the weight to dry fish. The result of this investigation reveated that salting gives extra weight and desired flavour as observed by Johnson and Esser (1991) The rate of mixing salt was found as $1 \mathrm{Kg}$ salt for $12 \mathrm{Kg}$ of fishes. Similar findings were mentioned by Galib and Samad (2009).

Salt is essential for proper fish drying. All the dry fish farmer used non brand commercial salt for low cost but Clueas and Ward (1996) recommended the use to good quality of salt. Drying duration extremely varied with weather conditions drying duration recorded to be varied from 2-5 days depending on the size of the raw fishes.

The hygienic condition of the commercial fish drying spots are very poor. There is no system of fly poor netting, the moist half dried fishes are prone to the attack blowfly larvae. Fisheries experts has been suggested that salting fish before drying gives protection against housefly infestation. The life cycles of all these insects involve four developmental stages, the egg, larva, pupa and adult (FAO, 1981).

Fish traders informed that the dry fishes are often infested by blowfly (Chrysomya sp.) and their larvae (maggot) during the phase especially in cloudy and rainy days and beetle (Neerobia and Dermestes sp.) and mites in the store causing considerable amount of weight loss of the finished products every year. The interviewee of the study area informed that the range annual production ranged from 6000 to $8000 \mathrm{Kg}$ of dry fish each year. This result was more or less similar to the findings of Azam (2002).

The price of dehydrated fish was comparatively high than the salted dried fish. The highest price per $\mathrm{Kg}$ of dried fish was found as 440-460 Tk. (Baim) Boal 2600 Tk and the lowest was found as 140-200 Tk. (Punti, Kholish, Darkina). This finding was more or less similar to the findings of Azam (2002).

Cost-benefit ratio of the fish drying point was found 1:0.671 fish drying point. Cost-benefit ratio of the fish drying point depended on total cost. This finding was more or less similar to the findings of Azam (2002).

The investigation found that after complete of drying all the dried fish stored at tent Jute sacks, bamboo baskets and polythene sheets were used for packaging. Rubbi et al. (1982) reported two types of packages for marketing of dried product i.e. fish wrapped inside gunny bag only and wrapped with polythene inside the gunny bag.

\section{Conclusions}

Traditional fish drying practice in Atrai reign playing an important role in the development of the dry fish farmer's socio-economic condition. This activities creates employment opportunities and supplying animal protein to the people. In most of the observed fish drying places, sun drying is carried out in an unhygienic condition, due to different reasons. If modified drying process are followed in commercial production, with proper hygiene and sanitation this product will fetch more higher price. Marketing distribution system of the dried fish needs to improved as well as reducing marketing chain.

\section{Acknowledgements}

The author wishes to his profound sense of gratitude sincere appreciation and indebtedness to his respected teacher and research supervisor Dr. Fawzia Adib Flowra, Associate Professor, Department of Fisheries University of Rajshahi for her scholastic guidance, valuable suggestions, affectionate feelings, constant encouragement and constructive criticisms and over all supervision throughout the study.

\section{Reference}

Ahmed M, 1978. Radiation disinfection studies on sun-dried fish. Proc. IPFC, 18: 310-321.

Alam MZ, 1971. Pests of stored grain and other stored products and their control. Dacca, Agricultural Information Service, $33 \mathrm{p}$.

Ali MH and AMM Hossain, 1986. An investigation on performance of fishermen's cooperative in fish catching practices in Bangladesh. Bangladesh J. Aquaculture, 8: 15-21.

Amla BL and SK Majumder, 1989. Food irradiation: A contribution to food security. In: Acceptance, control of and trade in irradiated food. Conf, Proc. Geneva. Jointly organised by FAO/ WHOAAEA. ITCUNTAD/GATT, IAEA, Vienna. pp. 63-71.

Azab AK, 1973. The biology of Dermestes maculatus Degeer (Coleoptera, Dermestidae). Bull. Soc. Entomol. Egypte, 56: 1-14.

Azam K, 2002. Fishermen Community of Kuakata, Bangladesh: Fisheries Activities and Quality of Dried Fish. Final Report, Support for University Fisheries Education and Research, DFID. 227p.

Bangladesh Bureau of Statistics (BBS), 2001. Statistical Year Book of Bangladesh. Govt. of the People's Republic of Bangladesh. March, 1993.p.204. 
BARC and CIRDAP, 1986.Socioeconomic aspects of fishing Community in Bangladesh and its rural development. A workshop jointly organized by Bangladesh Agricultural Research Council and Center of Integrated Rural Development for Asia and the pacific, Dhaka, June 10- 11.

Bhaumik U and PK Pandit, 1991. Socio-economic status of fishermen in some beds of West Bengal. Environment Ecol., 9: 600-603.

Bishaya KK, 1990. Problems and potentialities of beel fisheries, in Assam. Fishing Chimes, 910: 39-43.

Chong KC, 1979. An economic appraisal of the fisheries in the Chandpur, Muhuri, Halda and Ichamati project areas. Irrigation Fisheries Development Project. Working Document No. 13, DOF (Department of Fisheries), $19 \mathrm{pp}$.

Clueas IJ and AR Ward, 1996. Post-harvest Fisheries Development: A Guide to Handling, Preservation, Processing and Quality. Chatham Maritime, Kent ME4 4TB, United Kingdom. 429p.

Connell JJ, 2009. Some aspect of the texture of dehydrated fish. J Sci. Food Agric., 8: 326-537.

Cutting CL, 1962. The influence of drying, salting and smoking, on the nutritive value of fish. In: Fish in Nutrition. (eds. Heen, E. and Kreuzer, R.). Fishing News Books Ltd., London. pp. 161-179.

Daget J, 1966. Insect infeetion of African dried or smoked fish and the possibility of its control by irradiation. Application of food irradiation in developing countries. Tech. Rep. Ser. LQEA, 54:73-83.

Doe P, J Olley, N Haard and K Gopakumar, 1998. Methods for quality measurement Jn; Fish drying and smoking. Production and quality control. (ed. Doe, P.). Technomic Publishing Company Inc. U.S.A. pp. 117135.

DoF, 1990. Socio-economic conditions of fishermen in the eleven upazila of Patuakhali and Barguana district, Department of fisheries, Government of Bangladesh and Bay of Bengal. Program (BOBP/ FAO).

DoF, 2009. Jatio matshaw saptaho sankol 2009 (in Bengali). Department of Fisheries, Ministry of Fisheries and Livestock, Dhaka, Bangladesh. pp. 81-85.

DoF, 2011, Jatio matshow Sankol 2011 (in Bengali), Department of Fisheries, Ministry of Fisheries and Livestock.

Dyte CE, 1966. Studies the susceptibilities of the larvae of two hide beetles (Demestes sp., Coleoptera) to malathion. J Stored Prod. Res. 1:223-34

Esser JR, 1991. Biology of Chrysomya megacephala and reduction of losses that it causes to salted-dried fish in Southeast Asia. Bulletin of Entomological Research, 81:33-47.

FAO, 1981. The prevention of losses in cured fish. FAO Fisheries Technical No. 219. Food and Agriculture Organization of the United Nations, Rome. 87p.

Galib SM and MA Samad, 2009. Harvesting, traditional preservation and marketing of fishes of Chalan Beel, Bangladesh. Aquaculture Asia Magazine, XIV: 12-15.

Graikoski JT, 1973. Microbiology of cured and fermented fish. In: Microbial safety of fishery products. (eds. Chichester, C.Q. and Graham, H. D). pp. 97-110.

Green AA, 1967. The protection of dried sea-fish in South Arabia from infestation by Dermestesfrischi Kug (Coleoptera, Dermestidae). J Stored Prod Res., 2: 331-350.

Haq S and A Kamal, 1989. Bacteriological evaluation of traditionalfish products of Bangladesh. M.Sc. Thesis, Bangladesh Agricultural University, Mymensingh. 51 pp.

Hinton HE, 1955. Common insecipests of storedfood products. London, British Museum (Natural History), 2627.

Hossain MA, 1970. Marine and Freshwater fishes of the North-eastem part of Bay of Bengal. Res., 7: 26-55.

Huq A, MS Dey, HK Alam, SMN. and J Mahbub, M lah, 1986. Socio-economic study of typical fishing community in Bangladesh. A report Submitted to FAO Rome, 79P.

Hye MA, 1986. Socio-economic condition of Kaptai lake fishermen. Bangladesh J Ext. EA., 3: 27-23.

Kalaimani N and PV Kamasastri, 1988. Quality characteristics of cured fish of commerce. J Fish. Technol., 25: 54-57.

Kamruzzaman AKM, 1992. Qualitative evaluation of some commercially driedfish products of Bangladesh. M. Sc. Thesis, Department of Fisheries Technology, Bangladesh Agricultural University, Mymensingh. 37 pp.

Khaleque MA and MR Islam, 1985. The relative use and efficacy of common commercial and subsistence fishing gears in Bangladesh. Bangladesh J. Aquaculture, 6-7: 35-38.

Kuppuswarmy S, H Srinivason and V Subrahmanyam, 1958. Proteins in food. Indian Council of Medical Research. Spec. Rept. Series No. 33. New Delhi.

Lloyd CJ and CE Dyte, 1965. The susceptibility of larvae of Dmestes maculatus Degea (Coleoptera, Dermestidae) to some contact insecticides. J. Stored Prod Res, 159-167. 
Maclellan RH, 1964. A pyrethrum dipping treatment to protect dried fish from beetle infestation. Pyrethrum Post, 7:30-32.

Mansur MA, 1989. Biochemical quality assessment of some selectedfish species. M.Sc. Thesis. Department of Fisheries Technology, Bangladesh Agriculture University, Mymenshingh. 46pp.

Nowsad AA, 2005. Low cost processing of fish in coastal Bangadesh. Empowerment of coastal fishing communities for livelihood security. GOB/UNDP/FAO Project: BGD1971017: 512005. p.73.

Nowsad AKMA, 2007. Participatory Training of Trainers: A New Approach Applied in Fish Processing. 328p.

Nurullah M, M Kamal, Wahab, MA Islam, MN Yasmin, L Shakuntala, H Thilsted, and MA Mazid, (2005) Present status of harvesting, transportation and marketing of freshwater Small Indigenous Species of Fish (SIS) of Bangladesh, Bangladesh J. Fish. Res, 9: 159-168.

Osuji FNG, 1975. Some aspects of the biology of Dermestes maculatus Degeer (Coleoptera, Dermestidae) in dried fish. J. Stored Prod Res, 11:25-31.

Pervin S, 2004. Fumigation toxicity of plant derived compounds against Dermestes maculatus (Degeer) and Necrobia ruflpes (Degee) infesting dried fishes. M.Sc. thesis (unpublished), Department of Zoology, Rajshahi University, pp. 182.

Proctor DL, 1972. The protection of smoked dried freshwater fish from insect damage during storage in Zambia. J. Stored Prod Res, 8:139-49

Qudrat-I-Khuda M, NH Khan and JC Debnath, 1962. Biochemical and nutritional studies on East Pakistan fish, Part VIL Pakistan J. Sci. Ind Res. 5: 70-73.

Rahman M, 1992. A study on fish and fishermen of Kaptai lake in Bangladesh- BAU, Mymensingh and University Grants Commission, Dhaka, 49P,

Rubbi SF, Muslemuddin M, SS Jahan and M Begum, 1982. Storage of solar- tent dried pom.fret (Stomateus spp). In: The production and storage of dried fish. Proceedings of the workshop on the production and storage of dried fish. University Pertanian Malaysia, Serdang Malaysia. pp.93-100.

Samad A, 1993. An economic study on riverine fishing in a selected area of Sirajgonj district, M. Sc. Thesis submitted to the Department of Agriculture Finance, BAU, Mymensingh, 92 P.

Shewan JM, 1954. The bacteriology of dehydrated fish. 111. Observations and experiments made during smallscale commercial production. J. Hyg. 52:247-252.

Shewan JM and G Hobbs, 1967. The bacteriology of fish spoilage and preservation. Prog. Indus. Microbiol. 6: 169-208.

Toye SA, 1970. Studies on the humidity and temperature reactions of Dermestes maculatus Degeer with reference to infestation in dried fish in Nigeria. Bul. Entomol. Res, 60:23-3 1.

Troller JA and JHB Christian, 1978. Water activity and food. Academic Press. New York. pp. 216.

Tsai CH, MS Kong And BS Sunpan, 1989. Quality evaluation index of dried squid. 11. Quality index of dried squid as rehydrated food. Food Sci. 16:260-268.

Waterman, JJ, 1976. The production of dried fish. FA 0 Fish. Tech. Pap. 160: 52. 